Division of Geological \& Geophysical Surveys

PUBLIC-DATA FILE 93-39m

\title{
UNITED STATES GEOLOGICAL SURVEY \\ ALASKA MINERAL RESOURCE APPRAISAL PROGRAM (AMRAP) GEOCHEMICAL DATA FOR HEALY QUADRANGLE, ALASKA
}

by

S.A. Liss and M.A. Wiltse

June 1993

THIS REPORT HAS NOT BEEN REVIEWED FOR TECHNICAL CONTENT (EXCEPT AS NOTED IN TEXT) OR FOR CONFORMITY TO THE EDITORLAL STANDARDS OF DGGS.

Releasedby

STATE OFALASKA DEPARTMENT OP NATURAL RESOURCES

Division of Geological \& Geophysical Surveys

794 University Avenue, Suite 200

Fairbanks, Alaska 99709-3645 